\title{
NO STUDENT IS AN ISLAND: DEGRADATION OF INSTRUCTOR PRESENCE IN THE MULTI-SITE IS CLASSROOM
}

\author{
Thomas Lombardi, University of the Virgin Islands, thomas.lombardi@uvi.edu \\ Matthew North, Utah Valley University, mnorth@uvu.edu
}

\begin{abstract}
Distance education has taken on many forms and evolved tremendously with the advancement of new technologies, however impediments remain as we attempt to deliver instruction to student audiences across a variety of locations. This paper presents a case study which examines a particularly unique set of challenges: delivery of an information systems course to graduate students who live on disparate islands in the Caribbean. The authors examine a number of factors that impact student learning through both quantitative and qualitative means, concluding that the degradation of instructor presence, regardless of cause, is the primary reason for decreased student performance in the multi-site Information Systems classroom.
\end{abstract}

Keywords: Information Systems (IS), Instructional Technology, Distance Learning, Database Management

\section{INTRODUCTION}

The University of the Virgin Islands (UVI) is a multi-site university with campuses on islands separated by miles of open water. To facilitate learning at the lowest possible cost to students, classes are often delivered simultaneously to two or more classrooms using broadband video teleconferencing technology. This case study reviews and analyzes the learning environment for a graduate-level information systems course in an MBA program. In particular, the learning environment presented a number of challenges worthy of investigation including different student receptions based on student location (near or far), chosen instructional technique, and limited available technology. Anecdotal information suggested that the student location represented an important variable in student learning, but, much to our surprise, neither student location nor chosen instructional technique explained observed student performance in an empirical review of the available evidence. Upon reflection, the authors surmise that students in both locations responded similarly to the learning environment because the technology degraded the presence of the instructor.

In the Spring 2017 semester, Information Systems served 7 students on St. Thomas, the near location, and 11 students on St. Croix, the far location. Table 1 summarizes the enrolled student population in terms of location and gender. The gender composition of the class stands out: over $75 \%$ of the students in the class were female. In other words, the typical student in this section of Information Systems was a professional woman from the Caribbean participating in class from afar. By comparison, according to the AACSB, women comprised only $36 \%$ of those earning MBAs in 2015-2016 in the Caribbean and Latin America (AACSB, 2017). Moreover, the 2016 GMAC Application Trends Survey Report states that "women represent $37 \%$ of full-time two-year MBA applicants" (GMAC, 2016). Ostensibly the students in this section of Information Systems differed quite a bit from their counterparts in the typical MBA program.

Table 1. Demographic Breakdown of Enrolled Students in Information Systems

\begin{tabular}{|c|c|c|}
\hline Location & Female & Male \\
\hline St. Thomas (near) & 6 & 1 \\
\hline St. Croix (far) & 8 & 3 \\
\hline
\end{tabular}


The learning environment was as exceptional as the student body. The instructor, situated in St. Thomas, delivered the same course material synchronously to the students in St. Thomas and the students in St. Croix via videoconferencing technology. The learning environment had the following additional characteristics:

- Videoconferencing equipment: near and far cameras for student-student and student-teacher interaction.

- Classroom information technology: instructor's computer, projector, and document camera.

- Learning Management System: Blackboard.

- Student Equipment: personal cell phones.

- Small white boards not visible from the videoconferencing cameras.

- Class meetings lasted $21 / 2$ hours and convened once per week.

Moreover, the learning environment did not include the following:

- Neither the near nor the far location had support personnel in the class during the session.

- The students did not have access to computers in the classroom unless they brought personal laptops.

Table 2 summarizes the resources available in both locations. Overall, the learning environment focused on the technology required to deliver lectures in a multicast fashion to multiple sites in an efficient manner. As the instructor soon discovered, the technologies designed for delivering traditional lectures often created challenges for the active learning strategies devised at the outset of the semester.

Table 2. Summary of Available Resources

\begin{tabular}{|l|l|l|l|}
\hline \multicolumn{1}{|c|}{ Resource Type } & \multicolumn{1}{c|}{ Resource } & \multicolumn{1}{c|}{ Near Location } & \multicolumn{1}{c|}{ Far Location } \\
\hline Communications equipment & Videoconferencing & Yes & Yes \\
\hline Classroom equipment & Computer for instructor & Yes & Yes \\
\hline Classroom equipment & Projector & Yes & Yes \\
\hline Classroom equipment & Document camera & Yes & Yes \\
\hline Classroom equipment & White boards & $\begin{array}{l}\text { Yes, but not visible } \\
\text { to far location. }\end{array}$ & $\begin{array}{l}\text { Yes, but not visible to near } \\
\text { location. }\end{array}$ \\
\hline Classroom equipment & Computers for students & No & No \\
\hline Learning management system & Blackboard & Yes & Yes \\
\hline Personal equipment & Cell phones & Yes & Yes \\
\hline Classroom support & Support technician & On-call, not present & On-call, not present \\
\hline
\end{tabular}

In the first few weeks of class, a student contacted the instructor to relate problems with the course at the St. Croix location. Given the high energy costs in the U.S. Virgin Islands, classrooms have motion detectors to turn lights off automatically. Unfortunately, the lights turn off during class frequently distracting students from course content. Moreover, students in St. Croix reported that the instructor's voice often sounded far away and that it was difficult to hear the students at the St. Thomas location. These communication challenges were compounded by an air vent at the St. Croix location that often produced distracting noises further frustrating student efforts to engage with the class. Finally, students reported that the video screens projecting course content at the St. Croix location made it difficult to read the PowerPoint slides on the instructor's computer. In signal processing terms, the signal-to-noise ratio for the far location seemed to be far lower than that for near location.

The problems persisted throughout the first-half of the semester culminating in disappointing student retention and comprehension. The instructor decided to investigate the phenomenon with the hope of improving the student learning experience. A pre-test survey was devised to capture both general perceptions of the learning environment and course content. A corrective intervention based on active learning strategies was developed to compensate for the identified problems in the learning environment. In a post-test survey of course content, the survey supported some of the anecdotal information regarding students at the far location. An empirical review of student performance found no statistically significant differences between the near and far cohorts as had been anticipated. Given these results, the authors hypothesize that the instructor's presence was degraded in ways that adversely affected the far and near cohorts. 


\section{REVIEW OF LITERATURE}

The history of both synchronous and asynchronous distance learning is as extensive as it is broad. Research dating back decades investigates the methodologies and techniques used to facilitate communication, knowledge transfer, assessment, and instructional technologies. For the purposes of the present study we will focus our literature review primarily on the relevant aspects for our research questions: Is there a significant difference in demonstrated learning between near and far sites in a synchronous multi-site Information Systems classroom, and if so, what are the primary causes of the observed differences? Where possible, the authors have sought research that has specifically examined computing or technology teaching problems.

Distance learning was born of necessity. Even in its earliest forms--written correspondence courses handled through conventional mail--the catalyst for alternative teaching and learning emerged from a demand to separate instruction from the constraints of time and space (Sankey, 2012). As time and technologies have advanced, it is only natural that the drive for distance learning has incorporated use of emerging tools to close the gaps between instructors at one location and students at another (Adams, 2002; Arijana \& Dragan, 2005; Motamedi, 2001; Telg, 1996). In the present study, the motivation for multi-site course delivery is geographically driven: The University of the Virgin Islands services an area of more than 130 square miles ( $>200 \mathrm{sq} . \mathrm{km}$.), most of which is open ocean. With students hailing from the islands of St. Thomas, St. Croix, and St. John, along with a number of other islands in the Eastern Caribbean, getting all of the students together in the same place at the same time is both costly and time consuming. Thus, the need for distance education delivery is inherent to the place.

Faculty at UVI are not the first to face such challenges. From radio to television, from satellite to internet, instructors have long experimented with different delivery modes in an attempt to bring education to people, rather than force the people to come to the education (Hunt, Chalmers \& Macdonald, 2012; Marascovic \& Lutz, 2015). Throughout the adoption and adaptation of delivery technologies, scholarly efforts have been made to assess and report the impacts, the successes, failures and lessons learned along the path to delivering meaningful, effective instruction across time and space (Doggett, 2007; Saw, et al., 2008; Gibson, 2011; Raths, 2015). For the purposes of this study, we will focus on research and literature that addresses the use of technology to deliver instruction to multiple spaces, with emphasis on observed impacts on student comprehension and academic performance.

Experiences with instruction to multi-site classrooms has, perhaps unsurprisingly, varied. Ulrik (2011) reports that simply having a classroom technologist/assistant produced improved results, as reported by students, simply by separating the instructor's duties from the actual operation of the broadcasting technology. Ostensibly, this allowed instructors in Ulrik's report to apply their attentions to the course content and its delivery, rather than spending class time and attention (both theirs and their students') on getting the classroom technology to work. Ulrik acknowledges that not all teachers have the luxury of even a part-time classroom aid to assist with audiovisual equipment, a challenge also studied by Leonard (2003), Cornelius (2014), Rehn, Maor and McConney (2016a, 2016b), and others. The works by Rehn, et al. cited herein are particularly insightful in their treatment of this matter, specifically with the challenging need for synchronous multi-site instructors to juggle both broadcasting themselves and teaching their material (see also Roberts, 2009). This research is particularly relevant to our study, since the instructor here faces this very challenge: he must deliver his database design and development lessons each class period to two sites simultaneously without an in-class assistant, and in truth, with relatively limited technical support for the equipment he must use to reach students at the so-called far site.

With this challenge in mind, there are numerous examples of faculty members who have faced the same challenge and tested various innovations to address their needs. Kurose (2005) wrote of multiple ideas for ensuring that comprehension is achieved when working with students at a distance. Among the recommendations identified as effective for better reaching students is the use of mud-cards, or muddy-cards. At the end of a lesson, students at both near and far classroom locations are given an opportunity to write down any topics, concepts or vocabulary from the day's lesson that were particularly unclear (or in other words, were 'muddy' to their minds). This, of course, is not a technique unique to multi-site classrooms - it could be used in any instructional setting, however for confirming transfer of knowledge with more limited student/teacher contact, it has been shown to have a measurable positive effect (see Rutherford \& Rutherford, 2008; Abas, 2015). Whether through this or other techniques, ample research suggests that additional learning affirmation in a multi-site classroom is essential to improve achievement 
and to clarify ambiguities (Martin, 2005; Kaceski \& Koceska, 2013; Seidel, 2014). The authors discussed this technique and agreed it would be useful, however we did not test the use of mud cards for this study. Subsequently, this represents an opportunity for future research.

A major catalyst for undertaking the present study was to determine if the instructional communications technology was negatively affecting student learning, and if so, if students at the far site were more impacted than those in the live classroom (near site) with the instructor. A survey was conducted with the students, and we will briefly discuss the students' responses in our results section. The authors had certain expectations of what the students might report, and sought out prior investigations into the impact of video technology on students' learning, with specific interest in any examinations in a computing-related classroom.

Daley, Spalla, Arndt and Warnes (2008) examined the matter in a non-computing classroom and found that although students in far site classrooms sometimes perceived themselves to be at an instructional disadvantage, they often compensated for this by self-organizing into site specific learning communities, sometimes subconsciously, in order to feel better supported. Upon recognizing this, the researchers took intentional steps to encourage and facilitate learning community formation in a more intentional way. In more specifically computing-related courses, creation of a far site support community was also seen as helpful and even desirable (Hastie, Chen \& Kuo, 2007; Giesbers, Rienties, Gijselaers, Segers \& Tempelaar, 2009; Dumas, 2016). Writing in Computers \& Education specifically on this issue, Kear, Chetwynd, Williams \& Doneland (2012) found the formation of support groups was especially effective when facilitated by tutors. Learning communities, especially intentionally created ones, were observed to be beneficial in other multi-site classrooms where the content and subject matter were more technical in nature (Philip \& Mitra, 2012).

Even in instances where formal or informal learning support groups were not formed, there is evidence that interacting with an instructor at a distance, in and of itself, is not necessarily detrimental to student learning and knowledge transfer. Stafford and Lindsey (2007) report that they found that students at far site locations were often more motivated to seek out additional help or clarification on important course matters, and that the potential for distraction or disconnection because of telecommunication technology actually motivated students to increase their attention during class. This increased attention was self-reported rather than empirically measured in the Stafford study, but the conclusion is supported by similar observations by Sharon (2012) and Giesbers, Rienties, Tempelaar and Gijselaers (2013).

\section{Degradation of Presence}

As we proceeded with this current study, one theme regarding the multi-site nature of the course began to emerge, something that we have chosen to refer to as "degradation of presence". Even in situations where instructors have ample in-class technical support, where telecommunications technology and environment are not major distractors, there is a simple fact that not actually being there in person reduces the level of interpersonal interaction between teacher and learner. This is observed in the literature as well, with acknowledgements that in most cases, the ideal circumstance of support, technology and environment usually do not exist. Rehn (2017), working in rural Canada, rightly observes that the very nature of distance education and the catalyst for things like teleconferenced multi-site classrooms is due to limitations created by distance and a lack of advanced infrastructure. Are students in such locations to simply be excluded or ignored simply due to their location? Certainly not, and even with a degraded instructor presence, some level of access to desired education is better than none (see also Barbour, 2015). Both Parish (2008) and Qing, Moorman and Dyjur (2010) further examine this topic. For many years, living in a rural area meant either dedication of time and money to travel to obtain an education, or accepting defeat and not obtaining that education at all. From a desire to overcome both of these undesirable options, institutions have repeatedly opted to accept some measure of degradation of instructor presence in order to provide opportunity where none might otherwise exist.

Generally, students and instructors report that with ever-improving communications technologies, these efforts are working. As infrastructure is added, so too can educational programs be made available, often with an eager and committed student audience (Battalio, 2009; van Zyl, Els \& Blignaut, 2013). Students report a willingness to tolerate 
a certain amount of technical difficulty (Fitzgibbon, 2003) and even to offer extra efforts in order to compensate for deficiencies caused by an imperfect "far site" classroom environment in order to gain or maintain access to educational programs (Knipe \& Lee, 2002; Gilles, 2008). In some instances, ensuring that such programs continue to exist has deep and far-reaching effects on the communities served, increasing the sense of urgency to continue to deliver and improve them, any degradation issues notwithstanding (Lawrence, 2010; Iglesias \& Salgado, 2012; Messaoudi, et al., 2015). In all instances we reviewed, students appreciate and desire access to educational opportunities, even if a degradation of instructor presence occurs due to deficiencies in telecommunications technologies (Long, Logan, Cummins \& Waugh, 2016); instructors feel a sense of pride and accomplishment when facilitating access to education (Falloon, 2012; Tabak \& Rampal, 2014); and overall, pedagogical methods continue to improve (Keck, 1992; Bernard, et al. 2004; Kanuka, Rourke, \& Laflamme, 2007; Lawson, Comber, Gage \& Cullum-Hanshaw, 2010).

With the context set by this cited literature, and an enhanced understanding of the need for and importance of creating and maintaining education access, we began our study. Our desire is simply to improve the probability that learning will occur most effectively in the database design and implementation class, despite limitations created by technology, time and space, student populations, and instructional support. In truth, all instructors face at least some such limitations during their careers and must overcome them (Raca \& Dillenbourg, 2014). Our objective in this study is to contribute to instructional improvement when such challenges exist.

\section{RESEARCH METHODOLOGY}

Student and faculty frustrations about the challenges in the learning environment motivated this study. Therefore, this study is primarily action research: the authors endeavored to understand our students' struggles in the classroom and devise interventions to aid their learning. To put this anecdotal information into context, the instructor surveyed the students about the learning environment to gauge their experiences in the classroom. The instructor devised these questions to help revise course delivery to match the learning needs of the students:

Which of the following environmental factors presents the most serious challenges to your learning in this class?

$\begin{array}{ll}\text { Lighting } & 22.2 \% \\ \text { Air Conditioning } & 0 \% \\ \text { Video Quality } & 5.5 \% \\ \text { Sound Quality } & 27.7 \% \\ \text { Other } & 27.7 \%\end{array}$

Which of the following course format changes, if adopted for this class, would significantly improve your learning?

Online course format only $\quad 0 \%$

Hybrid course (half online) $\quad 22.2 \%$

Computer lab course $\quad 38.8 \%$

No new course format $\quad 38.8 \%$

would significantly improve

my learning (Keep current format)

In open ended responses, student comments often reflected the responses to the closed questions previously discussed. For example, students were given the following prompt in the survey: "In the space provided, please describe the challenges you face in the learning environment for this class." Some students echoed the $38 \%$ of students who found the current course format suitable: "I have not face [sic] any learning challenges based on the environment." Others clearly reflected the notion that the course would be improved if taught in a computer lab: "Due to the fact that this is a computer class, I actually taught [sic] that we would be in a computer class. I do realize that you do make it possible for us to use our cell phones and we do appreciate it, but I feel we are being done an injustice by not having computers. I feel we would move along much beter [sic]." These attitudes persisted 


\section{Issues in Information Systems}

Volume 18, Issue 3, pp. 40-52, 2017

even when we altered the question. When asked, "What changes to the course would significantly improve your learning in this class?", many students still expressed the desire for hands-on learning in a computer lab. Unfortunately, due to complex scheduling constraints and limited computer lab availability, computer lab access was not possible during the course session.

And yet, in some cases, students introduced new or unanticipated sources of noise that could serve as a starting point for revising course delivery. A few students cited practice examples related to the instructor's active learning strategy. In the words of one student: "So far, I am learning a lot in this class. The exercises during class helps to keep me engaged and aids my learning." Other students clearly responded to the lack of the instructor's presence in the far location: "If possible, having the professor teach the course in person maybe once a month or improving the sound and video quality." In one case, a student cited the instructor's accent as a source of noise in content reception: "I would like to say that I am learning alot [sic] in this course, though I miss one or two words as am still training my hear [sic] to the instructor's accent." From these responses, the instructor decided to rebalance the course to put hands-on exercises first with short lectures and discussions following each exercise.

In redesigning the course delivery, the instructor made the following assumptions:

- Lectures were largely ineffective due to the sources of noise evident in the student reports.

- The effects of the noise would be more severe for the far location than the near location.

- Active learning would promote better communication between the instructor and students by building in shorter feedback cycles.

The next section explains the sample exercises created to implement this new course delivery model. The results section evaluates these assumptions based on a review of midterm and survey results.

\section{Intervention Sample Exercises}

The active learning exercises integrated the available technologies to compensate for the lack of computing facilities. The exercises combine internet access, instructor's projector, document camera, cell phones, pens, notebooks and the Blackboard learning management system to allow teams of students to solve and review a series of design problems. The flow of each exercise works in roughly the same way. First, the instructor presents a problem via the projector to the whole class. The students solve the problem in groups on pen and paper. Each group photographs its solution and uploads it to Blackboard. Finally, the instructor conducts a review of each group's work and provides live solutions with the document camera where necessary. The cycle is repeated for each exercise ensuring that the feedback loop is closed before moving forward.

\section{Use Case Diagram Exercise}

Prompt: Draw a use case diagram that captures the actors, use cases, associations between actors and use cases and system boundary for the following use case descriptions.

User Description 1: Manager must be able to approve new content submitted by content creators in CMS. Manager must be able to submit new content to CMS

User Description 2: Content creator must be able to submit new content to CMS. Content creator must be able to edit content on CMS.

\section{ERD Exercise}

Given the following customer data, reorganize the data to reduce the redundancy in the current structure. Draw a crow's foot ERD diagram to capture your improved organization. Be sure to include primary keys, foreign keys, cardinality, data types and other relevant metadata in your solution. 


\begin{tabular}{|c|l|l|l|}
\hline Cust_ID & \multicolumn{1}{|c|}{ First_Name } & \multicolumn{1}{|c|}{ Last_Name } & \multicolumn{1}{c|}{ Phone_Number } \\
\hline 1 & Bob & Cobb & $777-111-1234$ \\
\hline 2 & Jane & Smith & $444-321-5432$ \\
\hline 1 & Bob & Cobb & $767-222-0987$ \\
\hline
\end{tabular}

Research Objective 1: Is there a significant difference in demonstrated learning between near (St. Thomas) and far (St. Croix) sites in a synchronous multi-site Information Systems classroom?

$\mathrm{H}_{1}$ : The midterm scores are significantly different in the near and far student cohorts.

$\mathrm{H}_{2}$ : The part 1 midterm scores are significantly different in the near and far student cohorts.

$\mathrm{H}_{3}$ : The specific question scores are significantly different in the near and far student cohorts.

To test $\mathrm{H}_{1}$ and $\mathrm{H}_{2}$, the authors calculated a two sample, two-tailed t-Test with equal variance assumptions to determine if the mean midterm and part 1 midterm scores differed significantly between the cohorts. For $\mathrm{H}_{3}$, we calculated Fisher's Exact Test for two midterm questions (\#7 and \#9) to determine if location could explain the patterns of correct and incorrect responses to these questions.

Research Objective 2: Are there pedagogical changes that can mitigate the low retention observed prior to the midterm?

Since student performance suffered on the midterm examination, the instructor devised a series of active learning interventions designed to mitigate the negative effects of the constraints of the learning environment. The active learning interventions followed a problem-based learning approach where students were given a problem and asked to design a solution by sketching their designs in a notebook. The students then used their cell phones to take pictures of their design documents and upload them to the Blackboard LMS. The instructor projected the uploaded design documents and organized student-led design reviews in the video-conferenced session.

$\mathrm{H}_{4}$ : The active learning intervention improved student comprehension of core concepts.

To test $\mathrm{H}_{4}$, the authors compared the answers to pre-intervention and post-intervention survey questions regarding core concepts.

\section{RESULTS}

In the evaluation of our first research objective, much to our surprise, the authors found no significant differences between the midterm scores of the near and far cohorts at the exam, section or question levels. Taken together, tables 3 and 4 demonstrate that the data provide no evidence of significant differences in the total midterm scores of our near and far cohorts. Similarly, tables 5 and 6 demonstrate that the data provide no evidence of significant differences in part 1 of the midterm examination. Tables 7 and 8 demonstrate that the data provide no evidence of an association between location and outcome on questions 7 and 9 of the midterm exam respectively. In other words, we have no evidence of significant differences in exam performance between the near and far students. Our proposed hypotheses do not explain the observed differences any better than random variation. 
Issues in Information Systems

Volume 18, Issue 3, pp. 40-52, 2017

Table 3. $H_{1}$ Descriptive Statistics

\begin{tabular}{|c|c|c|}
\hline Measurement & Near Cohort & Far Cohort \\
\hline Mean & 62.14 & 60.27 \\
\hline Variance & 267.8 & 214.0 \\
\hline Observations & 7 & 11 \\
\hline
\end{tabular}

Table 4. $\mathrm{H}_{1} t$-Test Results

\begin{tabular}{|c|c|}
\hline Measurement & Value \\
\hline Degrees of Freedom & 16 \\
\hline $\mathrm{t}$ Statistic & 0.252753 \\
\hline P-value & 0.8 \\
\hline
\end{tabular}

Table 5. $\mathrm{H}_{2}$ Descriptive Statistics

\begin{tabular}{|c|c|c|}
\hline Measurement & Near Cohort & Far Cohort \\
\hline Mean & 28.7 & 27.9 \\
\hline Variance & 126.2 & 52.1 \\
\hline Observations & 7 & 11 \\
\hline
\end{tabular}

Table 6. $\mathrm{H}_{2} t$-Test Results

\begin{tabular}{|c|c|}
\hline Measurement & Value \\
\hline Degrees of Freedom & 16 \\
\hline t Statistic & -0.186315 \\
\hline P-value & 0.85 \\
\hline
\end{tabular}

Table 7. $\mathrm{H}_{3}$ Results for Question \#7: $\mathrm{p}$-value $=0.15$

\begin{tabular}{|c|c|c|c|}
\hline & Correct & Incorrect & Total \\
\hline Near Cohort & 1 & 6 & 7 \\
\hline Far Cohort & 6 & 5 & 11 \\
\hline Total & 7 & 11 & 18 \\
\hline
\end{tabular}


Table 8. $\mathrm{H}_{3}$ Results for Question \#9: p-value $=0.33$

\begin{tabular}{|c|c|c|c|}
\hline & Correct & Incorrect & Total \\
\hline Near Cohort & 4 & 3 & 7 \\
\hline Far Cohort & 3 & 8 & 11 \\
\hline Total & 7 & 11 & 18 \\
\hline
\end{tabular}

In evaluating Research Objective 2, the authors noticed a modest improvement in students' ability to recognize an ERD as a format for capturing database design, albeit not a statistically significant change (Table 9). Overall, the intervention still represented a disappointing attempt to help students comprehend the data-oriented aspects of information systems.

Table 9. $\mathrm{H}_{4}$ Pre-Intervention and Post-Intervention Survey Questions

\begin{tabular}{|l|c|c|}
\hline \multicolumn{1}{|c|}{ Survey Question } & $\begin{array}{c}\text { Pre-Intervention Survey \% } \\
\text { of Correct Responses (n=18) }\end{array}$ & $\begin{array}{c}\text { Post-Intervention Survey \% } \\
\text { of Correct Responses (n=18) }\end{array}$ \\
\hline $\begin{array}{l}\text { What type of key uniquely identifies a record in a } \\
\text { table? (Primary Key) }\end{array}$ & $88.8 \%$ & $83.3 \%$ \\
\hline $\begin{array}{l}\text { What data type most appropriately stores a field } \\
\text { like data of birth? (Date) }\end{array}$ & $88.8 \%$ & $83.3 \%$ \\
\hline $\begin{array}{l}\text { Which of the following numbers could be validly } \\
\text { stored in a field defined as decimal (5,2)? (123.45) }\end{array}$ & $38.3 \%$ & $33.3 \%$ \\
\hline $\begin{array}{l}\text { Which data type most appropriately stores a field } \\
\text { with only two possible options: Y/N? (boolean) }\end{array}$ & $83.3 \%$ & $94.4 \%$ \\
\hline $\begin{array}{l}\text { Which documentation format captures entities, } \\
\text { attributes and the relationships between different } \\
\text { entities? (ERD) }\end{array}$ & $66.6 \%$ & $83.3 \%$ \\
\hline
\end{tabular}

The research methodologies for both objectives have the following threats to validity. Primarily, the statistical power for this study is exceptionally low making it nearly impossible to obtain reliably significant results. This is a result of the relatively small sample size of the class. Second, the demographic characteristics of the students in this class differ markedly from those in the typical MBA and graduate STEM courses. Due to our unique class makeup, we simply do not know how prior research applies to this demographic.

Despite the lack of statistically significant evidence, student reports demonstrate a clear preference for an instructor present in the room. Not a single student in the class indicated a preference for a purely online course format, despite the difficulties many students have balancing home, work and school responsibilities.

\section{CONCLUSION}

Based on our data collection and analysis, we have drawn a number of meaningful conclusions that will inform multi-site instruction going forward. It was very clear that:

1. The learning environment introduced a considerable amount of noise imposed by distance and the technologies employed to overcome the challenges of distance. 
2. Most students (roughly $60 \%$ ) desired course format changes of some kind.

3. No students wanted a purely online course.

4. We have no evidence of student location significantly affecting performance.

5. Our students want a present instructor.

\section{Recommendations}

Based on these clear observations, we make the following recommendations to ourselves, and to others faced with the challenges of teaching information systems topics in a multi-site instructional environment.

1. Teaching in new environments requires technical and pedagogical training.

2. The instructor's presence is an essential factor in reaching students from afar.

3. We need new approaches to researching small classes with atypical student populations. If we are serious about educating all students about information systems, we will need to develop research methodologies that address the needs of the students in our classes.

Ultimately, in spite of limitations which do degrade instructor presence, our research agrees with prior inquiry: access to educational opportunities that transcend the restrictions of time, space, finances, etc. are preferable to the alternative: no access to higher education programs. Acknowledging the existence of degradation of presence is the first step in addressing the problems created by it. The next step is to identify those elements that most contribute to degradation, knowing these will vary from site to site, class to class, and instructor to instructor. They are likely to include environmental challenges such as noise, temperature and classroom configuration; technology issues including sound, video and connectivity; and learning preference differences among the students. These can be addressed by working with facilities managers, adding technology when and where budgets will allow, and primarily, through frequent contact with students, soliciting and then specifically reacting to their feedback. As we move forward with this line of inquiry, we hope to test and report back on innovations that will improve the student learning experience, even in the face of the very limitations we, and all instructors in the multi-site classroom inevitably face.

\section{REFERENCES}

Abas, Z.W. (2015). 21st century education: Strategies to ignite and engage students. Journal of Institutional Research in South East Asia, 12(2), 5-16.

AACSB. (2017). Degrees Conferred Percentage by Gender, Level, and Region | AACSB Data. http://www.aacsb.edu/knowledge/data/frequently-requested/degrees-conferred/degrees-by-gender. Accessed on 5/3/2017.

Adams, S. (2002). Distance Education and Instructional Support at the University of South Carolina. College \& University Media Review, 8(2), 55-67.

Arijana, M., \& Dragan, P. (2005). Development and Application of Videoconferencing Systems. Promet (Zagreb), $17(2), 121-127$.

Barbour, M.K. (2015). Real-time virtual teaching: Lessons learned from a case study in a rural school. Online Learning, 19(5). Online.

Battalio, J. (2009). Success in Distance Education: Do Learning Styles and Multiple Formats Matter? The American Journal of Distance Education, 23, 71-87.

Bernard, R.M., Abram, P.C., Lou, Y., Borokhovski, E., Wade, A., Wozney, L. et al (2004). How does distance education compare with classroom instruction? A meta-analysis of the empirical literature. Review of Educational Research, 74, 379-439. 
Cornelius, S. (2014). Facilitating in a demanding environment: Experiences of teaching in virtual classrooms using web conferencing. British Journal of Educational Technology, 45(2), 260-271.

Daley, L., Spalla, T., Arndt, M., \& Warnes, A. (2008). Videoconferencing and Web-based conferencing to enhance learning communities. Journal of Nursing Education, 47(2), 78-81.

Doggett, A. M. (2007). The Videoconferencing Classroom: What Do Students Think? Journal of Industrial Teacher Education, 44(4), 29-41.

Dumas, J. (2016). Online vs. Face-to-Face student performance in an introduction to operating systems course. Journal of Computing Sciences in Colleges, 32(2), 185-191.

Falloon, G. (2011). Making the Connection: Moore's Theory of Transactional Distance and Its Relevance to the Use of a Virtual Classroom in Postgraduate Online Teacher Education. Journal Of Research On Technology In Education, 43(3), 187-209.

Fitzgibbon, P. (2003). Challenges of video-conferencing teaching and effective teaching methods. The Turkish Online Journal of Educational Technology, 2(4), 30-34.

Gibson, R. (2011). New Life for an Old Classroom. College \& University Media Review, 1769-76.

Giesbers, B., Rienties, B., Gijselaers, W. H., Segers, M. and Tempelaar, D. T. (2009). Social presence, Web videoconferencing and learning in virtual teams. Industry \& Higher Education, 23(4), 301-309.

Giesbers, B., Rienties, B., Tempelaar, D. \& Gijselaers, W. (2013). Investigating the relations between motivation, tool use, participation, and performance in an e-learning course using web-videoconferencing. Computers in Human Behaviour, 29(1), 285-292.

Gilles, D. (2008). Student perspectives on videoconferencing in teacher education at a distance. Distance Education, 29(1), 107-118.

Glassman, E. (2015). Mudslide: A Spatially Anchored Census of Student Confusion for Online Video Lectures. Proceedings of the 33rd Annual ACM Conference on Human Factors in Computing Systems, 1555-1564.

GMAC. (2016). Graduate Management Admission Council 2016 Application Trends Report. http://www.gmac.com/ /media/Files/gmac/Research/admissions-and-application-trends/2016-gmacapplication-trends-web-release-v2.pdf. Accessed on 5/3/2017.

Hastie, M., Chen, N., \& Kuo, Y. (2007). Instructional Design for Best Practice in the Synchronous Cyber Classroom. Educational Technology \& Society, 10(4), 281-294.

Hunt, L., Chalmers, D., \& Macdonald, R. (2012). University Teaching in Focus: A Learning-Centered Approach. Melbourne: ACER Press.

Iglesias, M., \& Salgado, J. F. (2012). Effectiveness of occupational training through videoconferencing: Comparison with classroom training and individual differences. Revista De Psicología Del Trabajo Y De Las Organizaciones, 28(3), 183-188.

Kaceski, S. \& Koceska, N. (2013). Challenges of videoconferencing distance education - a student perspective. International Journal of Information, Business and Management, 5(2), 274-314.

Kanuka, H., Rourke, L., and Laflamme, E. (2007). The influence of instruction methods on the quality of online discussion. British Journal of Educational Technology, 38(2), 260-271. 
Kear, K., Chetwynd, F., Williams, J., \& Donelan, H. (2012). Web Conferencing for Synchronous Online Tutorials: Perspectives of Tutors Using a New Medium. Computers \& Education, 58(3), 953-963.

Keck, J. (1992). Comparison of learning outcomes between graduate students in telecourses and those in traditional classrooms. Journal of Nursing Education, 31(5), 229-234.

Knipe, D. \& Lee, M. (2002). The quality of teaching and learning via video-conferencing. British Journal of Educational Technology, 33(3), 301-311.

Kurose, J. (2005). Reaching students at a distance: from videotape to the internet to online, interactive books. Journal of Computing Sciences in Colleges, 20(5), 228.

Lawrence, O. (2010). Global Internet Video Classroom: A Technology Supported Learner-Centered Classroom. Techtrends: Linking Research \& Practice to Improve Learning, 54(1), 50-53.

Lawson, T., Comber, C. Gage, J., \& Cullum-Hanshaw, A. (2010). Images of the future for education? Videoconferencing: a literature review. Technology, Pedagogy and Education, 19(3), 295-314.

Leonard, J. (2003). Classroom and support innovation using IP video and data collaboration techniques. Proceedings of the Fourth Conference on Information Technology Curriculum, 142 - 150.

Long, T., Logan, J., Cummins, J., \& Waugh, M. (2016). Students' and Instructors' Attitudes and Receptions of the Viability of Using a Flipped Classroom Instructional Model in a Technology-Enabled Active Learning (TEAL) Classroom: A Preliminary Study. Journal of Teaching and Learning with Technology. 5(1), 46-58.

Maher, M. Latulipe, C., Lipford, H., \& Rorrer, A. (2015). Flipped classroom strategies for CS Education. Proceedings of the 46th Technical Symposium on Computer Science Education, 218 - 223.

Marasovic, K. \& Lutz, M. (2015). Remote development and distance delivery of innovative courses: challenges and opportunities. Proceedings of the 37th Conference on Software Engineering, 2, 299 - 302.

Martin, M. (2005). Seeing is believing: The role of videoconferencing in distance learning. British Journal of Educational Technology, 36(3), 397-405.

Messaoudi, T., Bodin, F., Hidalgo Diaz, J., Ichihara, S., Fikry, T., Lacreuse, I., \& Facca, S. (2015). Evaluation of a new eLearning platform for distance teaching of microsurgery. Chirurgie De La Main, 34(3), 109-112.

Motamedi, V. (2001). A Critical Look at the Use of Videoconferencing in United States Distance Education. Education, 122(2), 386.

Parrish, M. (2008). Dancing the distance: iDance Arizona videoconferencing reaches rural communities. Research In Dance Education, 9(2), 187-208.

Philip, K., \& Mitra, S. (2012). Collaborative Learning amongst Distance Learners of Mathematics. Open Learning, 27(3), 227-247.

Qing, L., Moorman, L., \& Dyjur, P. (2010). Inquiry-based learning and e-mentoring via videoconference: a study of mathematics and science learning of Canadian rural students. Educational Technology Research \& Development, 58(6), 729-753.

Raca, M. \& Dillenbourg, P. (2014). Holistic Analysis of the Classroom. Proceedings of the 2014 Workshop on Multimodel Learning Analytics Workshop and Grand Challenge, 13 - 20.

Raths, D. (2015). 6 ways videoconferencing is expanding the classroom. T.H.E. Journal. Online. 
Rehn, N. (2017). Video-conferencing in rural and remote secondary education in Canada: A mixed-method collective case study of teachers' perceptions around presence, process and professional learning. Dissertation: Murdoch University.

Rehn, N., Maor, D., \& McConney, (2016). A. Investigating teacher presence in courses using synchronous videoconferencing. Distance Education, 37(3).

Rehn, N., Maor, D., \& McConney, A. (2016). Navigating the challenges of delivering courses by videoconference. British Journal of Educational Technology.

Rehn, N., Maor, D., \& McConney, A., (2015). The unique skills required of videoconference teachers in high school distance education courses: Implications for training and professional development. Teaching, Pedagogy and Education.

Roberts, R. (2009). Videoconferencing in distance learning: A New Zealand Schools' Perspective. Journal of Distance Learning, 13(1), 91-107.

Rutherford, R. \& Rutherford, J. (2008). Exploring teaching methods for online course delivery using universal instructional design. Proceedings of the 9th ACM SIGITE Conference on Information Technology Education, 45 - 50.

Sankey, M. (2012). Aligning your ducks for the student learning journey: Stories from the pond of distance ed. SITE2012.

Saw, K. G., Majid, O., Abdul Ghani, N., Atan, H., Idrus, R. M., Rahman, Z. A., \& Tan, K. E. (2008). The videoconferencing learning environment: Technology, interaction and learning intersect. British Journal of Educational Technology, 39(3), 475-485.

Seidel, N. (2014). Interaction Design Patterns for Design and Development of Video Learning Environments. Proceedings of the 19th European Conference on Pattern Languages of Programs.

Sharon G., H. (2012). Can You Hear Me Now? Assessing Students' Classroom Communication Preferences via a Telephone Conference Activity. Journal of Educators Online, 9(1).

Stafford, T. F., \& Lindsey, K. L. (2007). IP Teleconferencing in the Wired Classroom: Gratifications for Distance Education. Journal of Information Systems Education, 18(2), 227-232.

Tabak, F., \& Rampal, R. (2014). Synchronous E-Learning: Reflections and Design Considerations. International Journal of Education and Development Using Information and Communication Technology, 10(4), 80-92.

Telg, R. W. (1996). Instructional design considerations for teaching international audiences via satellite. International Journal of Instructional Media, 23(3), 209.

Ulrik, L. (2011). In the framework of videoconference classrooms at local learning centres in Sweden. European Journal for Research on the Education and Learning of Adults, 2(1), 89-105.

van Zyl, J. M., Els, C. J., \& Blignaut, A. S. (2013). Development of ODL in a Newly Industrialized Country According to Face-to-Face Contact, ICT, and E-Readiness. International Review of Research In Open And Distance Learning, 14(1), 84-105. 